\title{
Management of advanced ovarian cancer in Spain: an expert Delphi consensus
}

\author{
Andres Redondo ${ }^{1 *}$ (D), Ana Oaknin², Maria Jesus Rubio ${ }^{3}$, Maria-Pilar Barretina-Ginesta ${ }^{4}$, Ana de Juan ${ }^{5}$, Luis Manso ${ }^{6}$,
} Ignacio Romero ${ }^{7}$, Cristina Martin-Lorente ${ }^{8}$, Andres Poveda $^{9}$ and Antonio Gonzalez-Martin ${ }^{10}$

\begin{abstract}
Background: To determine the state of current practice and to reach a consensus on recommendations for the management of advanced ovarian cancer using a Delphi survey with a group of Spanish gynecologists and medical oncologists specially dedicated to gynecological tumors.

Methods: The questionnaire was developed by the byline authors. All questions but one were answered using a 9item Likert-like scale with three types of answers: frequency, relevance and agreement. We performed two rounds between December 2018 and July 2019. A consensus was considered reached when at least 75\% of the answers were located within three consecutive points of the Likert scale.

Results: In the first round, 32 oncologists and gynecologists were invited to participate, and 31 (96.9\%) completed the online questionnaire. In the second round, 27 (87.1\%) completed the online questionnaire. The results for the questions on first-line management of advanced disease, treatment of patients with recurrent disease for whom platinum might be the best option, and treatment of patients with recurrent disease for whom platinum might not be the best option are presented.

Conclusions: This survey shows a snapshot of current recommendations by this selected group of physicians. Although the majority of the agreements and recommendations are aligned with the recently published ESMOESGO consensus, there are some discrepancies that can be explained by differences in the interpretation of certain clinical trials, reimbursement or accessibility issues.
\end{abstract}

Keywords: Ovarian cancer, Advanced disease, Recurrent disease, Management, Consensus

\section{Background}

Worldwide, ovarian cancer comprised 3.4\% of all new cases of cancer in women in 2018 [1]. Despite the improvement of survival in recent decades among patients with advanced disease [2], ovarian cancer remains the leading cause of death among gynecological cancers in developed countries [3].

As in other oncology settings, the treatment of ovarian cancer is continuously evolving. Thus, although new

\footnotetext{
*Correspondence: andres.redondos@uam.es

'Medical Oncology Department, Hospital Universitario La Paz-IdiPAZ,

Universidad Autónoma de Madrid, Paseo de la Castellana, 261, 28046 Madrid, Spain

Full list of author information is available at the end of the article
}

treatment options for primary and recurrent ovarian cancer have improved outcomes for patients, they have also increased the complexity of the management of this condition, and several areas of controversy exist.

Although one of the objectives of clinical practice guidelines for ovarian cancer is to improve and harmonize the management of the disease and the availability of several clinical practice guidelines [4-6], considerable variation exists among countries in both the recommendations and clinical practice regarding the management of this neoplasm $[7,8]$. Additionally, adherence to the clinical practice guidelines is not always optimal [9, 10], and this might have an impact on patient outcomes, including

(c) The Author(s). 2021 Open Access This article is licensed under a Creative Commons Attribution 4.0 International License, which permits use, sharing, adaptation, distribution and reproduction in any medium or format, as long as you give appropriate credit to the original author(s) and the source, provide a link to the Creative Commons licence, and indicate if changes were made. The images or other third party material in this article are included in the article's Creative Commons licence, unless indicated otherwise in a credit line to the material. If material is not included in the article's Creative Commons licence and your intended use is not permitted by statutory regulation or exceeds the permitted use, you will need to obtain permission directly from the copyright holder. To view a copy of this licence, visit http://creativecommons.org/licenses/by/4.0/ The Creative Commons Public Domain Dedication waiver (http://creativecommons.org/publicdomain/zero/1.0/) applies to the data made available in this article, unless otherwise stated in a credit line to the data. 
survival, as well as the efficiency of the healthcare system $[7,11,12]$.

The objective of this study was to determine the state of current practice and to reach a consensus on recommendations for the management of advanced ovarian cancer using a Delphi survey with a group of Spanish medical oncologists specially dedicated to gynecological tumors.

\section{Results}

\section{Response rate}

In the first round, 32 oncologists and gynecologists were invited to participate, and 31 (96.9\%) completed the online questionnaire. In the second round, the 31 firstround respondents were invited to participate, and 27 (87.1\%) completed the online questionnaire.

\section{First-line management of advanced disease}

Detailed responses to all questions in this section, including the location, proportion, and strength (i.e., median) of consensus, are presented in Table 1.

The initial assessment for resectability always includes computed tomography $(\mathrm{CT})$ of the thorax, abdomen and pelvis according to the vast majority of the respondents. Positron emission tomography (PET)-CT and laparoscopy are sometimes used (median 5 and 6, respectively), while diffusion-weighted whole-body magnetic resonance imaging (MRI) is rarely performed (median 1). There was consensus for recommending a postsurgical CT scan for all patients both for those undergoing primary surgery and those undergoing interval surgery (median 8 in both cases).

There was consensus in using primary debulking surgery (PDS) instead of neoadjuvant chemotherapy (NACT) followed by interval debulking surgery (IDS) for patients with stage III disease considered suitable for primary debulking (median 9), but consensus was not reached for selecting this strategy as the primary strategy when minimal residual disease is expected to be left after surgery (median 6). Regarding patients with stage IV disease, if they are considered suitable for debulking surgery, two-thirds of the respondents preferred to start with PDS instead of NACT in the subgroup of patients with inguinal adenopathy or patients with positive pleural effusion (Fig. 1). A consensus with a high degree of agreement (100\% responding 8-9, median 9) was reached in recommending IDS after NACT unless there is tumor progression or the tumor is considered unresectable.

There was no agreement for recommending intraperitoneal chemotherapy for either of the two proposed clinical scenarios. However, an important proportion of participants $(59 \%)$ fairly to fully agreed (median 7 ) to recommend it for patients with optimal cytoreduction if their physical condition allows it.
Regarding the addition of bevacizumab to paclitaxel and carboplatin, the respondents agreed to recommend this approach in patients who underwent primary surgery if they have stage IV (median 9) or stage III cancer with macroscopic residual disease $>1 \mathrm{~cm}$ (median 9). Similarly, there was agreement in recommending adding bevacizumab after IDS for patients who require NACT when there is macroscopic residual disease or for stage IV patients (median 9).

\section{Treatment of patients with recurrent disease for whom platinum might be the best option}

The specific responses to the 13 questions of this section and measures of consensus are presented in Table 2.

For selecting the treatment for patients with a treatment-free interval of platinum (TFIp) exceeding 6 months, there was consensus among respondents that the following 9 factors, ordered by degree of relevance, should be taken into account: BRCA status, histological subtype, performance status (median 9 for these 3 factors), location and extent of the disease, drugs already received and number of prior lines, residual toxicity, symptoms, comorbidities and patient preferences (median 8 for these 6 factors). The magnitude of the TFIp (6-12 vs $>12$ months) was not considered a very relevant factor (median 7).

A consensus was reached (median 9) to recommend somatic $B R C A$ testing at the time of relapse for patients with germline nonmutated $B R C A$ if somatic testing had not been performed at diagnosis.

The participants agreed that for patients with recurrent disease and a TFIp exceeding 6 months, a secondary cytoreductive surgery should be considered if the patient meets the so-called AGO (Arbeitsgemeinschaft Gynäkologische Onkologie- German Working Group on Gynecological Oncology) score used in the DESKTOP III trial (ECOG 0, complete resection at primary surgery and the absence of large volume [ $>500 \mathrm{~mL}]$ ascites) and after assessment of the extension using PET-CT to rule out unresectable disease (median 8 in both cases). In patients with subsequent relapse after secondary cytoreductive surgery and a TFIp $>6$ months, there was no agreement in considering tertiary cytoreductive surgery for selected patients (median 7).

In the BRCA-mutated recurrent $O C$ population, platinum-based chemotherapy followed by a PARP inhibitor (PARPi) was considered the treatment of choice if the patients have not previously been treated with PARPi, regardless of previous treatment with bevacizumab (median 9). Consistently, for these patients, the combination of a doublet containing carboplatin with bevacizumab is infrequently used (median 3 ).

In the BRCA nonmutated population who has not received a prior PARPi, regardless of previous treatment with bevacizumab, there was no consensus for 
Table 1 First-line management of advanced-stage ovarian cancer

\begin{tabular}{|c|c|c|c|c|c|c|c|c|c|c|c|c|}
\hline \multirow{2}{*}{$\begin{array}{l}\text { Question/issue } \\
\text { 1.Please, indicate how often you perform the following } \\
\text { methods in your clinical practice to assess the initial } \\
\text { resectability of a patient with advanced ovarian cancer }\end{array}$} & \multirow{2}{*}{$\frac{\text { Round }}{1^{\text {st }}}$} & \multicolumn{9}{|c|}{ Likert-scale score } & \multirow[t]{2}{*}{$\% \mathrm{C}$} & \multirow[t]{2}{*}{ M } \\
\hline & & $\begin{array}{c}1 \\
\text { Never. }\end{array}$ & 2 & $\begin{array}{l}3 \\
\text { Few } \\
\text { times }\end{array}$ & 4 & \begin{tabular}{c|}
$\mathbf{5}$ \\
Some- \\
times
\end{tabular} & 6 & $\begin{array}{l}7 \\
\text { Many } \\
\text { times }\end{array}$ & 8 & $\begin{array}{c}\mathbf{9} \\
\text { Always }\end{array}$ & & \\
\hline CT scan thorax, abdomen, and pelvis & & - & - & 6.5 & - & - & - & - & 6.5 & 87.0 & 93.5 & 9 \\
\hline PET-CT & & - & 9.7 & 16.1 & 3.2 & 38.7 & 12.9 & 12.9 & 3.2 & 3.2 & 64.5 & 5 \\
\hline Diffusion-weighted whole-body MRI & & 61.3 & 9.7 & 3.2 & 12.9 & 3.2 & 9.7 & 12.9 & 3.2 & 3.2 & 74.2 & 1 \\
\hline Laparoscopy & & - & - & 16.1 & - & 25.8 & 9.7 & 32.3 & 9.7 & - & 67.8 & 6 \\
\hline \multirow[t]{2}{*}{$\begin{array}{l}\text { 2.In patients with stage III ovarian cancer considered } \\
\text { feasible for debulking by a tumor committee, I prefer } \\
\text { primary surgery to neoadjuvant chemotherapy followed } \\
\text { by interval surgery }\end{array}$} & $1^{\text {st }}$ & $\begin{array}{c}1 \\
\text { Fully } \\
\text { Disagr. }\end{array}$ & 2 & $\begin{array}{c}3 \\
\text { Fairly } \\
\text { Disagr }\end{array}$ & 4 & $\begin{array}{l}\mathbf{5} \\
\text { Neither } \\
\text { agree } \\
\text { nor } \\
\text { disagree }\end{array}$ & 6 & $\begin{array}{l}7 \\
\text { Fairly } \\
\text { Agree }\end{array}$ & 8 & $\begin{array}{c}9 \\
\text { Fully } \\
\text { Agree }\end{array}$ & & \\
\hline & & - & - & 3.2 & - & - & - & 9.7 & 16.1 & 71.0 & 96.8 & 9 \\
\hline \multirow[t]{2}{*}{$\begin{array}{l}\text { 3. I consider as primary choice a primary surgery of } \\
\text { maximum effort, even if the result is a minimal residual } \\
\text { disease after surgery }(>0 \text { and }<1 \mathrm{~cm} \text { ) rather than } \\
\text { performing neoadjuvant chemotherapy followed by } \\
\text { interval surgery }\end{array}$} & $2^{\text {nd }}$ & $\begin{array}{c}1 \\
1 \\
\text { Fully } \\
\text { Disagr. }\end{array}$ & 2 & $\begin{array}{c}3 \\
\text { Fairly } \\
\text { Disagr }\end{array}$ & 4 & \begin{tabular}{|l|}
$\mathbf{5}$ \\
Neither \\
agree \\
nor \\
disagree
\end{tabular} & 6 & $\begin{array}{c} \\
\begin{array}{c}7 \\
\text { Fairly } \\
\text { Agree }\end{array}\end{array}$ & 8 & $\begin{array}{c}9 \\
\text { Fully } \\
\text { Agree }\end{array}$ & & \\
\hline & & 7.4 & 3.7 & 29.6 & - & 7.4 & 7.4 & 29.6 & 3.7 & 11.1 & 44.4 & 6 \\
\hline \multirow[t]{2}{*}{$\begin{array}{l}\text { 4.I recommend performing a post-surgical CT scan to all } \\
\text { patients after primary surgery }\end{array}$} & $1^{\text {st }}$ & $\begin{array}{c}1 \\
\text { Fully } \\
\text { Disagr. }\end{array}$ & 2 & $\begin{array}{c}3 \\
\text { Fairly } \\
\text { Disagr }\end{array}$ & 4 & \begin{tabular}{|c|}
$\mathbf{5}$ \\
Neither \\
agree \\
nor \\
disagree
\end{tabular} & 6 & $\begin{array}{c}7 \\
\begin{array}{c}\text { Fairly } \\
\text { Agree }\end{array}\end{array}$ & 8 & $\begin{array}{c}9 \\
\text { Fully } \\
\text { Agree }\end{array}$ & & \\
\hline & & - & - & 3.2 & - & - & - & 29.0 & 29.0 & 38.8 & 96.8 & 8 \\
\hline \multirow[t]{2}{*}{$\begin{array}{l}\text { 5. I recommend a post-surgical CT scan to all patients } \\
\text { after interval surgery. }\end{array}$} & $1^{\text {st }}$ & $\begin{array}{c}1 \\
\text { Fully } \\
\text { Disagr. }\end{array}$ & 2 & $\begin{array}{c}3 \\
\text { Fairly } \\
\text { Disagr }\end{array}$ & 4 & $\begin{array}{c}\mathbf{5} \\
\text { Neither } \\
\text { agree } \\
\text { nor } \\
\text { disagree }\end{array}$ & 6 & $\begin{array}{l}7 \\
\text { Fairly } \\
\text { Agree }\end{array}$ & 8 & $\begin{array}{c}9 \\
\text { Fully } \\
\text { Agree }\end{array}$ & & \\
\hline & & - & 3.2 & 3.2 & - & 3.2 & 3.2 & 29.0 & 16.1 & 41.9 & 87.0 & 8 \\
\hline \multirow[t]{2}{*}{$\begin{array}{l}\text { 6. I recommend interval surgery after } 3 \text { cycles (maximum } \\
\text { 4) of neoadjuvant chemotherapy unless there is tumor } \\
\text { progression or it is considered unresectable at that time }\end{array}$} & $1^{\text {st }}$ & $\begin{array}{c}1 \\
\text { Fully } \\
\text { Disagr. }\end{array}$ & 2 & $\begin{array}{c}3 \\
\text { Fairly } \\
\text { Disagr }\end{array}$ & 4 & \begin{tabular}{|c|}
$\mathbf{5}$ \\
Neither \\
agree \\
nor \\
disagree
\end{tabular} & 6 & $\begin{array}{l}7 \\
\text { Fairly } \\
\text { Agree }\end{array}$ & 8 & $\begin{array}{c}9 \\
\text { Fully } \\
\text { Agree }\end{array}$ & & \\
\hline & & - & - & - & - & - & - & - & 9.7 & 90.3 & 100 & 9 \\
\hline \multirow[t]{2}{*}{$\begin{array}{l}\text { 7. I believe that patients with optimal cytoreduction } \\
\text { (absence of residual macroscopic disease) should receive } \\
\text { treatment with intraperitoneal chemotherapy if their } \\
\text { physical condition allows }\end{array}$} & $2^{\text {nd }}$ & $\begin{array}{c}\mathbf{1} \\
\text { Fully } \\
\text { Disagr. }\end{array}$ & 2 & $\begin{array}{c}3 \\
\text { Fairly } \\
\text { Disagr }\end{array}$ & 4 & \begin{tabular}{c|}
$\mathbf{5}$ \\
Neither \\
agree \\
nor \\
disagree \\
\end{tabular} & 6 & $\begin{array}{l}7 \\
\text { Faily } \\
\text { Agree }\end{array}$ & 8 & $\begin{array}{c}9 \\
\text { Fully } \\
\text { Agree }\end{array}$ & & \\
\hline & & - & 7.4 & 14.8 & 11.1 & 3.7 & 3.7 & 22.0 & 18.5 & 18.5 & 59.0 & 7 \\
\hline \multirow[t]{2}{*}{$\begin{array}{l}8 . \text { I believe that patients with macroscopic residual } \\
\text { disease }<1 \mathrm{~cm} \text { should receive treatment with } \\
\text { intraperitoneal chemotherapy if their physical condition } \\
\text { allows }\end{array}$} & $2^{\text {nd }}$ & $\begin{array}{c}1 \\
\text { Fully } \\
\text { Disagr. }\end{array}$ & 2 & $\begin{array}{l}3 \\
\text { Fairly } \\
\text { Disagr }\end{array}$ & 4 & $\begin{array}{c}\mathbf{5} \\
\text { Neither } \\
\text { agree } \\
\text { nor } \\
\text { disagree }\end{array}$ & 6 & $\begin{array}{l}7 \\
\text { Failly } \\
\text { Agree }\end{array}$ & 8 & $\begin{array}{c}9 \\
\text { Fully } \\
\text { Agree }\end{array}$ & & \\
\hline & & 14.8 & 7.4 & 14.8 & 3.7 & 11.1 & 7.4 & 29.6 & 3.7 & 7.4 & 48.1 & 5 \\
\hline $\begin{array}{l}\text { 9. In patients undergoing primary surgery I recommend } \\
\text { adding bevacizumab to paclitaxel and carboplatin in: }\end{array}$ & & $\begin{array}{c}1 \\
\text { Fully } \\
\text { Disagr. }\end{array}$ & 2 & $\begin{array}{l}3 \\
\text { Fairly } \\
\text { Disagr }\end{array}$ & 4 & $\begin{array}{l}\mathbf{5} \\
\text { Neither } \\
\text { agree } \\
\text { nor } \\
\text { disagree }\end{array}$ & 6 & $\begin{array}{l}7 \\
\text { Fairly } \\
\text { Agree }\end{array}$ & 8 & $\begin{array}{c}9 \\
\text { Fully } \\
\text { Agree }\end{array}$ & & \\
\hline $\begin{array}{l}\text { a. All patients with stage IIIB onwards regardless of } \\
\text { tumor residue }\end{array}$ & $2^{\text {nd }}$ & 7.4 & 18.5 & 40.7 & 3.7 & - & 3.7 & 18.5 & 3.7 & 3.7 & 66.6 & 3 \\
\hline b. In patients with stage IV disease & $1^{\text {st }}$ & - & - & - & - & - & - & 22.6 & 12.9 & 64.5 & 100 & 9 \\
\hline $\begin{array}{l}\text { c. In patients with stage III and macroscopic residual } \\
\text { disease }>1 \mathrm{~cm}\end{array}$ & $1^{\text {st }}$ & - & - & - & - & - & - & 12.9 & 16.1 & 71.0 & 100 & 9 \\
\hline $\begin{array}{l}\text { d. In patients with stage III and macroscopic residual } \\
\text { disease } \leq 1 \mathrm{~cm}\end{array}$ & $2^{\text {nd }}$ & - & 3.7 & 7.4 & 7.4 & 7.4 & 3.7 & 33.3 & 18.5 & 18.5 & 70.3 & 7 \\
\hline \multicolumn{13}{|l|}{$\begin{array}{l}\text { 10. In patients who require neoadjuvant chemotherapy } \\
\text { and interval surgery, I recommend adding bevacizumab }\end{array}$} \\
\hline $\begin{array}{l}\text { a. To all patients since the beginning of neoadjuvant } \\
\text { therapy }\end{array}$ & $2^{\text {nd }}$ & 29.6 & 25.9 & 25.9 & 3.7 & 3.7 & 3.7 & 7.4 & - & - & 81.4 & 2 \\
\hline $\begin{array}{l}\text { b. Only after interval surgery, regardless of tumor } \\
\text { residue }\end{array}$ & $2^{\text {nd }}$ & 11.1 & 14.8 & 7.4 & 7.4 & 7.4 & 7.4 & 18.5 & 11.1 & 14.8 & 44.4 & 6 \\
\hline $\begin{array}{l}\text { c. Only after interval surgery when there is } \\
\text { macroscopic tumor residue or if it is a stage IV } \\
\text { disease }\end{array}$ & $2^{\text {nd }}$ & - & 3.7 & 7.4 & & & 7.4 & 14.8 & 11.1 & 55.6 & 81.5 & 9 \\
\hline
\end{tabular}

\% C proportion of consensus, CT Computed tomography, M Median, MRI Magnetic resonance imaging, PET-CT Positron emission tomography-computed tomography

Black shadowed areas represent the presence of consensus (i.e., $\geq 75 \%$ of the responses are located within those three consecutive points of the Likert scale) Gray shadowed areas represent the triplet with a greater proportion of responses but without reaching consensus threshold 


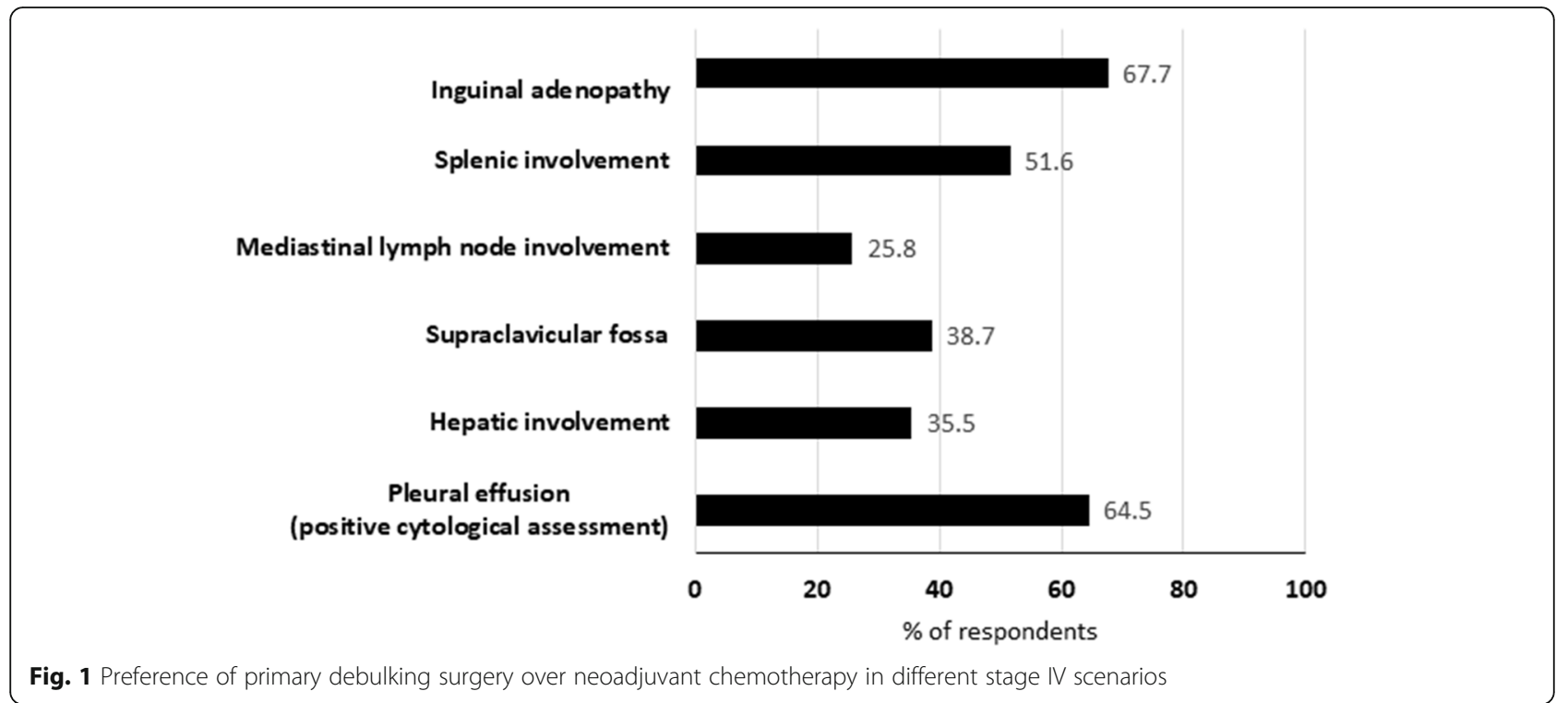

recommending platinum-based chemotherapy followed by a PARPi or platinum-based chemotherapy with bevacizumab. The latter option is infrequently used for patients who have received first-line treatment with bevacizumab.

The respondents agreed that the following factors are relevant for deciding the addition of bevacizumab to platinum-based chemotherapy: BRCA mutation status (median 9), history of intestinal subocclusion (median 9), presence of ascites or large pleural effusion (median 7), and presence of symptoms (median 7).

The combination of pegylated liposomal doxorubicin with trabectedin was only recommended as a valid strategy for patients with a history of platinum hypersensitivity regardless of the TFIp (6-12 vs $>12$ months) and $B R C A$ status (median 7 for $B R C A$ mutated and nonmutated).

\section{Treatment of patients with recurrent disease for whom platinum might not be the best option}

The results of the 7 questions for this section are presented in Table 3.

There was consensus that patients could be considered ineligible for platinum in the following clinical situations: patients who have had tumor progression during platinum treatment (median 9), patients who have shown hypersensitivity to platinum and are not candidates for a desensitization protocol (median 9), and patients with a TFIp $<6$ months without a BRCA mutation (median 7). One-third of the participants showed a high degree of agreement that a TFIp $<6$ months by itself defines ineligibility for platinum regardless of the $B R C A$ mutation status, while another third of the respondents disagreed with this statement (median 5).
Factors considered more relevant (median degree of relevance 8-9) for determining the therapeutic option for patients who are ineligible for platinum were performance status, the patient's desire, residual toxicity and the presence of symptoms. The most frequent therapeutic option used for these patients is treatment within a clinical trial whenever possible (median 9), followed by single agent chemotherapy in combination with bevacizumab (median 7). When using bevacizumab, most of the respondents agreed that the preferred chemotherapy is weekly paclitaxel (median 8).

The most relevant factors to be taken into consideration for not using bevacizumab in this population are a recent (<6 months) history of subocclusion and poor performance status (median 7 in both cases); although the cutoff for consensus was not reached, a recent history of grade 3 deep vein thrombosis or pulmonary thromboembolism, history of poorly controlled hypertension and, to a relatively lower extent, previous lines of treatment were also considered relevant factors for not selecting bevacizumab (median 7 in all cases).

If the patient is not eligible for platinum because of a history of hypersensitivity to carboplatin, the preferred approach is platinum rechallenge following a desensitization protocol (median 7). Platinum rechallenge is also the preferred option for a patient who was initially defined as ineligible for platinum due to a TFIp $<6$ months and has been treated with several lines of nonplatinum regimens, showing a clinical benefit and maintaining a good performance status (median 7).

\section{Discussion}

This expert consensus survey aimed to provide a snapshot of the current practice and expert recommendations for 
Table 2 Recurrent ovarian cancer: treatment of patients eligible for platinum

\begin{tabular}{|c|c|c|c|c|c|c|c|c|c|c|c|c|}
\hline \multirow[b]{2}{*}{$\begin{array}{l}\text { Question/issue } \\
\text { 1. To choose the treatment of relapse with platinum- } \\
\text { free interval (Treatment Free interval of platinum: } \\
\text { TFIp) }>6 \text { months, several factors must be taken into } \\
\text { account: }\end{array}$} & \multirow[t]{2}{*}{ Round } & \multicolumn{9}{|c|}{ Likert-scale score } & \multirow[t]{2}{*}{$\% \mathrm{C}$} & \multirow[t]{2}{*}{$M$} \\
\hline & & $\begin{array}{c}1 \\
\text { Scarcely } \\
\text { relevant }\end{array}$ & 2 & $\begin{array}{c}3 \\
\text { Slightly } \\
\text { relevant }\end{array}$ & 4 & $\begin{array}{l}\mathbf{5} \\
\text { Moder- } \\
\text { ately } \\
\text { relevant }\end{array}$ & 6 & $\begin{array}{c}7 \\
\text { Fairly } \\
\text { relevant }\end{array}$ & 8 & $\begin{array}{c}9 \\
\text { Very } \\
\text { relevant }\end{array}$ & & \\
\hline a. Location and extent of the disease & $2^{\text {nd }}$ & 3.7 & - & - & - & 11.1 & - & 25.9 & 14.8 & 44.4 & 81.5 & 8 \\
\hline b. Histological subtype & $2^{\text {nd }}$ & - & - & 3.7 & 7.4 & 3.7 & 3.7 & 22.7 & 7.4 & 51.9 & 81.5 & 9 \\
\hline c. BRCA status & $1^{\text {st }}$ & - & - & - & - & - & - & 3.2 & 12.9 & 83.9 & 100 & 9 \\
\hline $\begin{array}{l}\text { d. Magnitude of the platinum free interval (6-12 } \\
\text { months vs }>12 \text { months) }\end{array}$ & $2^{\text {nd }}$ & - & 3.7 & - & - & 22.2 & 11.1 & 37.0 & 3.7 & 22.2 & 70.3 & 7 \\
\hline e. Drugs and number of lines received & $1^{\text {st }}$ & - & - & - & - & 3.2 & 6.5 & 32.3 & 19.4 & 38.7 & 90.4 & 8 \\
\hline f. Residual toxicity & $1^{\text {st }}$ & - & - & - & - & 6.5 & - & 25.8 & 19.4 & 48.4 & 93.6 & 8 \\
\hline g. Symptoms & $1^{\text {st }}$ & - & - & 3.2 & - & 6.5 & - & 38.7 & 16.1 & 35.4 & 90.3 & 8 \\
\hline h. General health status & $1^{\text {st }}$ & - & - & - & - & - & 3.2 & 16.1 & 25.8 & 54.8 & 96.7 & 9 \\
\hline i. $\quad$ Comorbidities & $1^{\text {st }}$ & - & - & - & - & - & 9.7 & 32.3 & 16.1 & 41.9 & 90.3 & 8 \\
\hline j. Patients' preferences & $1^{\text {st }}$ & - & - & - & 3.2 & 3.2 & 3.2 & 25.8 & 22.6 & 41.9 & 90.3 & 8 \\
\hline $\begin{array}{l}\text { 2. To propose a secondary cytoreduction in a patient } \\
\text { with relapse and TFIp }>6 \text { months, what would be } \\
\text { your degree of agreement with each of the } \\
\text { following statements }\end{array}$ & & $\begin{array}{c}1 \\
\text { Fully } \\
\text { Disagr. }\end{array}$ & 2 & $\begin{array}{c}3 \\
\text { Fairly } \\
\text { Disagr }\end{array}$ & 4 & $\begin{array}{l}\mathbf{5} \\
\text { Neither } \\
\text { agree } \\
\text { nor } \\
\text { disagree }\end{array}$ & 6 & $\begin{array}{l}7 \\
\text { Fairly } \\
\text { Agree }\end{array}$ & 8 & $\begin{array}{c}9 \\
\text { Fully } \\
\text { Agree }\end{array}$ & & \\
\hline $\begin{array}{l}\text { a. I usually consider it in patients who meet the } \\
\text { criteria of the Desktop III study (first relapse + } \\
\text { AGO-score: complete primary cytoreduction, } \\
\text { ascites }<500 \mathrm{ml} \text { and ECOG 0) }\end{array}$ & $2^{\text {nd }}$ & - & - & - & - & 3.7 & - & 44.4 & 33.3 & 18.5 & 96.2 & 8 \\
\hline $\begin{array}{l}\text { b. Before making the decision together with the } \\
\text { surgeon, we conducted an extension study with } \\
\text { PET-CT to rule out unresectable disease }\end{array}$ & 1st & - & 6.5 & 3.2 & - & 6.5 & - & 16.1 & 19.4 & 48.4 & 83.4 & 8 \\
\hline $\begin{array}{l}\text { c. This option should be assessed whenever the } \\
\text { surgeon considers that he can achieve complete } \\
\text { cytoreduction, regardless of the AGO-score or } \\
\text { the extent of the disease }\end{array}$ & $2^{\text {nd }}$ & 3.7 & - & 11.1 & 7.4 & 3.7 & 11.1 & 44.4 & 14.8 & 3.7 & 70.3 & 7 \\
\hline \multirow[t]{2}{*}{$\begin{array}{l}\text { 3. In successive relapses with TFIp > } 6 \text { months, I assess } \\
\text { new possibilities of cytoreduction (tertiary, etc.) in } \\
\text { selected patients }\end{array}$} & & $\begin{array}{c}\mathbf{1} \\
\text { Fully } \\
\text { Disagr. }\end{array}$ & 2 & $\begin{array}{c}3 \\
\text { Fairly } \\
\text { Disagr }\end{array}$ & 4 & $\begin{array}{l}\mathbf{5} \\
\text { Neither } \\
\text { agree } \\
\text { nor } \\
\text { disagree }\end{array}$ & 6 & $\begin{array}{l}7 \\
\text { Fairly } \\
\text { Agree }\end{array}$ & 8 & $\begin{array}{c}9 \\
\text { Fully } \\
\text { Agree }\end{array}$ & & \\
\hline & $2^{\text {nd }}$ & 11.1 & - & 3.7 & - & 14.8 & 11.1 & 40.7 & 14.8 & 3.7 & 66.6 & 7 \\
\hline \multirow[t]{2}{*}{$\begin{array}{l}\text { 4. If, at the time of relapse, the germinal BRCA status } \\
\text { is not mutated, the somatic BRCA status must be } \\
\text { determined }\end{array}$} & & $\begin{array}{c}1 \\
\text { Fully } \\
\text { Disagr. }\end{array}$ & 2 & $\begin{array}{c}3 \\
\text { Fairly } \\
\text { Disagr }\end{array}$ & 4 & $\begin{array}{c}\mathbf{5} \\
\text { Neither } \\
\text { agree } \\
\text { nor } \\
\text { disagree }\end{array}$ & 6 & $\begin{array}{l}7 \\
\text { Fairly } \\
\text { Agree }\end{array}$ & 8 & $\begin{array}{c}9 \\
\text { Fully } \\
\text { Agree }\end{array}$ & & \\
\hline & $1^{\text {st }}$ & 3.2 & - & - & 3.2 & 3.2 & 3.2 & 29.0 & 3.2 & 54.8 & 87.0 & 9 \\
\hline \multirow[t]{2}{*}{$\begin{array}{l}\text { 5. The treatment of choice in patients with BRCA } \\
\text { mutation not previously treated with a PARP } \\
\text { inhibitor would be a combination of platinum } \\
\text { followed by an approved PARP inhibitor in that } \\
\text { situation, regardless of whether or not they } \\
\text { previously received treatment with bevacizumab. }\end{array}$} & & $\begin{array}{c}1 \\
\text { Never. }\end{array}$ & 2 & $\begin{array}{c}3 \\
\text { Few } \\
\text { times }\end{array}$ & 4 & $\begin{array}{c}\mathbf{5} \\
\text { Some- } \\
\text { times }\end{array}$ & 6 & $\begin{array}{l}\mathbf{7} \\
\text { Many } \\
\text { times }\end{array}$ & 8 & $\begin{array}{c}9 \\
\text { Always }\end{array}$ & & \\
\hline & $1^{\text {st }}$ & - & - & - & - & - & - & 12.9 & 38.7 & 48.4 & 100 & 8 \\
\hline \multirow[t]{2}{*}{$\begin{array}{l}\text { 6. In a BRCA-mutated patient who has not received } \\
\text { first-line bevacizumab or a PARP inhibitor } \\
\text { previously, do you use a platinum doublet } \\
\text { (carboplatin/gemcitabine or carboplatin/paclitaxel) } \\
\text { in your clinical practice with bevacizumab? }\end{array}$} & & $\begin{array}{c}1 \\
\text { Never. }\end{array}$ & 2 & $\begin{array}{c}\text { 3 } \\
\text { Few } \\
\text { times }\end{array}$ & 4 & $\begin{array}{l}\mathbf{5} \\
\text { Some- } \\
\text { times }\end{array}$ & 6 & $\begin{array}{l}7 \\
\text { Many } \\
\text { times }\end{array}$ & 8 & $\begin{array}{c}\mathbf{9} \\
\text { Always }\end{array}$ & & \\
\hline & $1^{\text {st }}$ & 19.4 & 25.8 & 32.3 & 3.2 & 16.1 & - & - & - & - & 77.5 & 3 \\
\hline \multirow[t]{2}{*}{$\begin{array}{l}\text { 7. In a BRCA mutation patient who has received } \\
\text { bevacizumab in the first line and has not previously } \\
\text { received a PARP inhibitor, do you use a platinum } \\
\text { doublet (carboplatin/gemcitabine or } \\
\text { carboplatin/paclitaxel) with bevacizumab in your } \\
\text { clinical practice? }\end{array}$} & & $\begin{array}{c}1 \\
\text { Never. }\end{array}$ & 2 & $\begin{array}{c}\mathbf{3} \\
\text { Few } \\
\text { times }\end{array}$ & 4 & $\begin{array}{c}\mathbf{5} \\
\text { Some- } \\
\text { times }\end{array}$ & 6 & $\begin{array}{c}\mathbf{7} \\
\text { Many } \\
\text { times }\end{array}$ & 8 & $\begin{array}{c}9 \\
\text { Always }\end{array}$ & & \\
\hline & $1^{\text {st }}$ & 45.2 & 29.0 & 16.1 & - & 6.5 & 3.2 & - & - & - & 90.3 & 2 \\
\hline
\end{tabular}


Table 2 Recurrent ovarian cancer: treatment of patients eligible for platinum (Continued)

\begin{tabular}{|c|c|c|c|c|c|c|c|c|c|c|c|c|}
\hline $\begin{array}{l}\text { 8. What relevance does it give to the following factors } \\
\text { to decide whether or not to opt for bevacizumab as } \\
\text { a treatment associated with platinum in the first } \\
\text { relapse with TFIp> } 6 \text { months? }\end{array}$ & & $\begin{array}{c}\mathbf{1} \\
\text { Scarcely } \\
\text { relevant }\end{array}$ & 2 & $\begin{array}{c}\mathbf{3} \\
\text { Slightly } \\
\text { relevant }\end{array}$ & 4 & $\begin{array}{l}\mathbf{5} \\
\text { Moder- } \\
\text { ately } \\
\text { relevant }\end{array}$ & 6 & $\begin{array}{c}\mathbf{7} \\
\text { Fairly } \\
\text { relevant }\end{array}$ & 8 & $\begin{array}{c}\mathbf{9} \\
\text { Very } \\
\text { relevat }\end{array}$ & & \\
\hline a. Presence of symptoms & $2^{\text {nd }}$ & - & 3.7 & - & - & 7.4 & 11.1 & 33.3 & 22.2 & 22.2 & 77.7 & 7 \\
\hline b. Presence of ascites or large pleural effusion & $2^{\text {nd }}$ & 3.7 & 3.7 & - & - & 3.7 & 3.7 & 44.4 & 11.1 & 29.6 & 85.1 & 7 \\
\hline c. Presence of peritoneal carcinomatosis & $2^{\text {nd }}$ & 7.4 & 7.4 & 7.4 & 3.7 & 18.5 & 14.8 & 29.6 & 11.1 & - & 62.9 & 6 \\
\hline d. Episodes of intestinal pseudo-occlusion & $2^{\text {nd }}$ & - & - & - & - & - & 11.1 & 25.9 & 11.1 & 51.9 & 88.9 & 9 \\
\hline e. BRCA mutation status & $2^{\text {nd }}$ & - & 3.7 & 3.7 & - & - & - & 14.8 & 25.9 & 51.9 & 92.6 & 9 \\
\hline f. Nonserous histology/high-grade endometrium & $2^{\text {nd }}$ & - & 7.4 & 3.7 & - & 14.8 & 11.1 & 33.3 & 11.1 & 18.5 & 62.9 & 7 \\
\hline \multirow[t]{2}{*}{$\begin{array}{l}\text { 9. The treatment of choice in patients without BRCA } \\
\text { mutation who have not received a PARP inhibitor } \\
\text { would be a combination of platinum followed by an } \\
\text { approved PARP inhibitor in that situation, regardless } \\
\text { of whether or not they previously received } \\
\text { treatment with bevacizumab }\end{array}$} & $2^{\text {nd }}$ & $\begin{array}{c}\mathbf{1} \\
\text { Fully } \\
\text { Disagr. }\end{array}$ & 2 & $\begin{array}{l}3 \\
\text { Fairly } \\
\text { Disagr }\end{array}$ & 4 & $\begin{array}{c}\mathbf{5} \\
\text { Neither } \\
\text { agree } \\
\text { nor } \\
\text { disagree }\end{array}$ & 6 & $\begin{array}{l}7 \\
\text { Fairly } \\
\text { Agree }\end{array}$ & 8 & $\begin{array}{c}9 \\
9 \\
\text { Fully } \\
\text { Agree }\end{array}$ & & \\
\hline & & - & 3.7 & 11.1 & 3.7 & 14.8 & 7.4 & 40.7 & 3.7 & 14.8 & 62.9 & 7 \\
\hline \multirow[t]{2}{*}{$\begin{array}{l}\text { 10. In a patient without BRCA mutation who has not } \\
\text { received bevacizumab in the first line or a PARP } \\
\text { inhibitor previously, do you use a platinum double } \\
\text { (carboplatin/gemcitabine or carboplatin/carboplatin } \\
\text { /paclitaxel) in your clinical practice with } \\
\text { bevacizumab? }\end{array}$} & & $\begin{array}{c}1 \\
\text { Never }\end{array}$ & 2 & $\begin{array}{c}3 \\
\text { Few } \\
\text { times }\end{array}$ & 4 & $\begin{array}{l}\mathbf{5} \\
\text { Some- } \\
\text { times }\end{array}$ & 6 & $\begin{array}{c}7 \\
\text { Many } \\
\text { times }\end{array}$ & 8 & $\begin{array}{c}9 \\
\text { Always }\end{array}$ & & \\
\hline & $1^{\text {st }}$ & 3.2 & 3.2 & 22.6 & - & 22.6 & 19.4 & 25.8 & 3.2 & - & 67.8 & - \\
\hline \multirow[t]{2}{*}{$\begin{array}{l}\text { 11. In a patient without BRCA mutation who has } \\
\text { received bevacizumab in the first line and has not } \\
\text { previously received a PARP inhibitor, do you use a } \\
\text { platinum doublet (carboplatin/gemcitabine or } \\
\text { carboplatin/carboplatin/paclitaxel) in your clinical } \\
\text { practice with bevacizumab? }\end{array}$} & & $\begin{array}{c}\mathbf{1} \\
\text { Never }\end{array}$ & 2 & $\begin{array}{c}\mathbf{3} \\
\text { Few } \\
\text { times }\end{array}$ & 4 & $\begin{array}{c}\mathbf{5} \\
\text { Some- } \\
\text { times }\end{array}$ & 6 & $\begin{array}{c}\mathbf{7} \\
\text { Many } \\
\text { times }\end{array}$ & 8 & $\begin{array}{c}\mathbf{9} \\
\text { Always }\end{array}$ & & \\
\hline & $1^{\text {st }}$ & 38.7 & 16.1 & 22.6 & - & 9.7 & 6.5 & 3.2 & 3.2 & - & 77.4 & 2 \\
\hline $\begin{array}{l}\text { 12. The combination of pegylated liposomal } \\
\text { doxorubicin-trabectedin in the population with } \\
\text { nonmutated BRCA can be considered valid in the } \\
\text { following scenarios: }\end{array}$ & & $\begin{array}{c}\mathbf{1} \\
\text { Fully } \\
\text { Disagr. }\end{array}$ & 2 & $\begin{array}{c}\mathbf{3} \\
\text { Fairly } \\
\text { Disagr }\end{array}$ & 4 & $\begin{array}{l}\mathbf{5} \\
\text { Neither } \\
\text { agree } \\
\text { nor } \\
\text { disagree }\end{array}$ & 6 & $\begin{array}{c}7 \\
\text { Fairly } \\
\text { Agree }\end{array}$ & 8 & $\begin{array}{c}\mathbf{9} \\
\text { Fully } \\
\text { Agree }\end{array}$ & & \\
\hline $\begin{array}{l}\text { a. When there is a history of hypersensitivity to } \\
\text { platinum regardless of TFIp, 6-12 months or }>12 \\
\text { months. }\end{array}$ & $2^{\text {nd }}$ & - & 3.7 & 3.7 & 3.7 & - & 3.7 & 40.7 & 22.2 & 22.2 & 85.1 & 7 \\
\hline $\begin{array}{l}\text { b. In the second line (first relapse) with TFIp } \\
\text { between } 6 \text { and } 12 \text { months, whether or not they } \\
\text { received bevacizumab in the first line }\end{array}$ & $2^{\text {nd }}$ & 7.4 & 18.5 & 25.9 & 3.7 & 3.7 & 14.8 & 14.8 & 7.4 & 3.7 & 51.8 & 3 \\
\hline $\begin{array}{l}\text { c. From the third line with TFIp between } 6 \text { and } 12 \\
\text { months, whether or not they have previously } \\
\text { received a PARP inhibitor or bevacizumab }\end{array}$ & $2^{\text {nd }}$ & 3.7 & 18.5 & 7.4 & 7.4 & 14.8 & 18.5 & 25.9 & - & 3.7 & 59.2 & 5 \\
\hline $\begin{array}{l}\text { d. From the third line with TFIp between } 6 \text { and } 12 \\
\text { months, only when you have previously received } \\
\text { a PARP inhibitor and bevacizumab }\end{array}$ & $2^{\text {nd }}$ & 7.4 & 7.4 & 7.4 & 3.7 & 25.9 & 7.4 & 29.6 & 7.4 & 3.7 & 62.9 & 5 \\
\hline $\begin{array}{l}\text { 13. The combination of pegylated liposomal } \\
\text { doxorubicin-trabectedin in the population with } \\
\text { mutated BRCA can be considered valid in the } \\
\text { following scenarios: }\end{array}$ & & $\begin{array}{c}\mathbf{1} \\
\text { Fully } \\
\text { Disagr. }\end{array}$ & 2 & $\begin{array}{c}\mathbf{3} \\
\text { Fairly } \\
\text { Disagr }\end{array}$ & 4 & $\begin{array}{l}\mathbf{5} \\
\text { Neither } \\
\text { agree } \\
\text { nor } \\
\text { disagree }\end{array}$ & 6 & $\begin{array}{c}\mathbf{7} \\
\text { Fairly } \\
\text { Agree }\end{array}$ & 8 & $\begin{array}{c}\mathbf{9} \\
\text { Fully } \\
\text { Agree }\end{array}$ & & \\
\hline $\begin{array}{l}\text { a. When there is a history of hypersensitivity to } \\
\text { platinum, regardless of TFIp, 6-12 months or }>12 \\
\text { months. }\end{array}$ & $2^{\text {nd }}$ & 7.4 & - & 7.4 & 3.7 & - & - & 51.9 & 18.5 & 11.1 & 81.5 & 7 \\
\hline $\begin{array}{l}\text { b. In the second line (first relapse) with TFIp } \\
\text { between } 6 \text { and } 12 \text { months, whether or not they } \\
\text { have received bevacizumab in the first line }\end{array}$ & $2^{\text {nd }}$ & 11.1 & 37.0 & 11.1 & 11.1 & 11.1 & 7.4 & 7.4 & - & 3.7 & 59.2 & 3 \\
\hline $\begin{array}{l}\text { c. From the third line with TFIp between } 6 \text { and } 12 \\
\text { months, whether or not they have previously } \\
\text { received a PARP inhibitor or bevacizumab }\end{array}$ & $2^{\text {nd }}$ & 14.8 & 44.4 & 7.4 & 18.5 & 3.7 & 3.7 & 3.7 & - & 3.7 & 70.3 & 2 \\
\hline $\begin{array}{l}\text { d. From the third line with TFIp between } 6 \text { and } 12 \\
\text { months, only when the patient has previously } \\
\text { received a PARP inhibitor and bevacizumab }\end{array}$ & $2^{\text {nd }}$ & 7.4 & 3.7 & 3.7 & - & 22.5 & 11.1 & 18.5 & 33.3 & - & 62.9 & 7 \\
\hline
\end{tabular}

AGO Arbeitsgemeinschaft Gynäkologische Onkologie (German Working Group on Gynecological Oncology), \% C proportion of consensus, ECOG Eastern Cooperative Oncology Group, M Median, PARP Poly(ADP-ribose) polymerase, PET-CT Positron emission tomography-computed tomography, TFIp Treatment-free interval of platinum

Black shadowed areas represent the presence of consensus (i.e., $\geq 75 \%$ of the responses are located within those three consecutive points of the Likert scale) Gray shadowed areas represent the triplet with greater proportion of responses but without reaching the consensus threshold 
Table 3 Recurrent ovarian cancer: treatment of patients non-eligible for platinum

\begin{tabular}{|c|c|c|c|c|c|c|c|c|c|c|c|c|}
\hline \multirow{2}{*}{$\begin{array}{l}\text { Question/issue } \\
\text { 1. For each of the following clinical situations, what is } \\
\text { your degree of agreement to consider that these are } \\
\text { patients not candidates for platinum: }\end{array}$} & \multirow[t]{2}{*}{ Round } & \multicolumn{9}{|c|}{ Likert-scale score } & \multirow[t]{2}{*}{$\% \mathrm{C}$} & \multirow[t]{2}{*}{ M } \\
\hline & & $\begin{array}{c}\mathbf{1} \\
\text { Fully } \\
\text { Disagr. }\end{array}$ & 2 & $\begin{array}{c}3 \\
\text { Fairly } \\
\text { Disagr }\end{array}$ & 4 & \begin{tabular}{|c|}
$\mathbf{5}$ \\
Neither \\
agree \\
nor \\
disagree
\end{tabular} & 6 & $\begin{array}{l}7 \\
\text { Fairly } \\
\text { Agree }\end{array}$ & 8 & $\begin{array}{c}9 \\
\text { Fully } \\
\text { Agree }\end{array}$ & & \\
\hline $\begin{array}{l}\text { a. Those patients who have a tumor progression } \\
\text { during platinum treatment }\end{array}$ & $1^{\text {st }}$ & - & - & - & - & - & - & 3.2 & 3.2 & 93.5 & 100 & 9 \\
\hline $\begin{array}{l}\text { b. Those patients with a platinum free interval of } \\
\text { less than } 6 \text { months, regardless of BRCA status }\end{array}$ & 2nd & - & 7.4 & 29.6 & 11.1 & 3.7 & 14.8 & 25.9 & 3.7 & 3.7 & 48.1 & 5 \\
\hline $\begin{array}{l}\text { c. Those patients with a platinum free interval }<6 \\
\text { months without mutation in BRCA }\end{array}$ & $1^{\text {st }}$ & - & - & 3.2 & 9.7 & 3.2 & 6.5 & 38.7 & 22.6 & 16.1 & 77.4 & 7 \\
\hline $\begin{array}{l}\text { d. Those patients with platinum-free interval }<6 \\
\text { months with BRCA mutation }\end{array}$ & 2nd & 11.1 & 22.2 & 29.6 & 11.1 & 7.4 & 3.7 & 3.7 & 7.4 & 3.7 & 62.9 & 3 \\
\hline $\begin{array}{l}\text { e. Patients with hypersensitivity to platinum not } \\
\text { susceptible to being subjected to desensitization } \\
\text { protocol }\end{array}$ & $1^{\text {st }}$ & 3.2 & 3.2 & 6.5 & - & - & 3.2 & 12.9 & 9.7 & 61.3 & 83.9 & 9 \\
\hline $\begin{array}{l}\text { 2. How relevant are the following factors when } \\
\text { deciding the therapeutic option in a nonplatinum } \\
\text { candidate patient: }\end{array}$ & & $\begin{array}{c}1 \\
\text { Poorly } \\
\text { relevant }\end{array}$ & 2 & $\begin{array}{c}\mathbf{3} \\
\text { Slightly } \\
\text { relevant }\end{array}$ & 4 & $\begin{array}{c}\mathbf{5} \\
\text { Moder- } \\
\text { ately } \\
\text { relevant }\end{array}$ & 6 & $\begin{array}{c}7 \\
\text { Fairly } \\
\text { relevant }\end{array}$ & 8 & $\begin{array}{c}\mathbf{9} \\
\text { Strongly } \\
\text { relevant }\end{array}$ & & \\
\hline a. General health status (ECOG) & $1^{\text {st }}$ & - & - & - & - & - & 6.5 & 12.9 & 9.0 & 71.0 & 93.6 & 9 \\
\hline b. Presence of symptoms & $1^{\text {st }}$ & - & - & - & - & 12.6 & - & 19.4 & 22.6 & 45.2 & 87.2 & 8 \\
\hline c. Residual toxicity to previous lines & $1^{\text {st }}$ & - & - & - & - & 6.5 & 6.5 & 22.8 & 16.1 & 48.4 & 96.7 & 8 \\
\hline d. The patient's desire to receive treatment & $1^{\text {st }}$ & - & - & - & - & 3.2 & - & 25.8 & 16.1 & 54.8 & 96.7 & 9 \\
\hline $\begin{array}{l}\text { 3. Indicate the frequency in which you use in your } \\
\text { clinical practice each of the following therapeutic } \\
\text { options in patients not candidates for platinum: }\end{array}$ & & $\begin{array}{c}1 \\
\text { Never. }\end{array}$ & 2 & $\begin{array}{c}3 \\
\text { Few } \\
\text { times }\end{array}$ & 4 & $\begin{array}{l}\mathbf{5} \\
\text { Some- } \\
\text { times }\end{array}$ & 6 & $\begin{array}{c}7 \\
\text { Many } \\
\text { times }\end{array}$ & 8 & $\begin{array}{c}\mathbf{9} \\
\text { Always }\end{array}$ & & \\
\hline a. Treatment within clinical trial, whenever possible & $1^{\text {st }}$ & - & - & - & - & 6.5 & 3.2 & 12.9 & 9.7 & 67.7 & 90.3 & 9 \\
\hline b. Support treatment only & $1^{\text {st }}$ & - & 6.5 & 38.7 & 6.5 & 38.7 & 6.5 & - & - & 3.2 & 83.9 & 4 \\
\hline $\begin{array}{l}\text { c. Single agent chemotherapy (e.g., weekly } \\
\text { paclitaxel or pegylated liposomal doxorubicin) }\end{array}$ & $1^{\text {st }}$ & - & 3.2 & 3.2 & - & 22.6 & 12.9 & 38.7 & 16.1 & 3.2 & 74.2 & 7 \\
\hline d. Chemotherapy in combination with bevacizumab & $1^{\text {st }}$ & - & - & - & - & 6.5 & 16.1 & 51.6 & 22.6 & 3.2 & 90.3 & 7 \\
\hline $\begin{array}{l}\text { 4. When you consider using bevacizumab in } \\
\text { nonplatinum candidates, how relevant are the } \\
\text { following factors in your decision: }\end{array}$ & & $\begin{array}{c}1 \\
\text { Poorly } \\
\text { relevant }\end{array}$ & 2 & $\begin{array}{l}3 \\
\text { Slightly } \\
\text { relevant }\end{array}$ & 4 & $\begin{array}{l}\mathbf{5} \\
\text { Moder- } \\
\text { ately } \\
\text { relevant }\end{array}$ & 6 & $\begin{array}{c}7 \\
\text { Fairly } \\
\text { relevant }\end{array}$ & 8 & $\begin{array}{l}9 \\
\text { Strongly } \\
\text { relevant }\end{array}$ & & \\
\hline $\begin{array}{l}\text { a. The presence of intestinal subocclusion in the } \\
\text { previous } 6 \text { months episodes. }\end{array}$ & $2^{\text {nd }}$ & - & - & - & - & 11.1 & 3.7 & 44.4 & 7.4 & 33.3 & 85.1 & 7 \\
\hline $\begin{array}{l}\text { b. History of grade } 3 \text { deep vein thrombosis or } \\
\text { pulmonary thromboembolism in the last } 6 \\
\text { months }\end{array}$ & $2^{\text {nd }}$ & - & - & 3.7 & 3.7 & 18.5 & - & 40.7 & 11.1 & 22.2 & 74.0 & 7 \\
\hline c. History of poorly controlled hypertension & $2^{\text {nd }}$ & - & 3.7 & 3.7 & - & 14.8 & 3.7 & 37.0 & 18.5 & 18.5 & 74.0 & 7 \\
\hline d. Previous lines of treatment & $2^{\text {nd }}$ & 7.4 & 3.7 & 14.8 & - & 11.1 & 3.7 & 29.6 & 7.4 & 22.2 & 59.2 & 7 \\
\hline e. General health status & $2^{\text {nd }}$ & - & 3.7 & - & 3.7 & 11.1 & - & 48.1 & 3.7 & 29.6 & 81.4 & 7 \\
\hline $\begin{array}{l}\text { 5. When I use bevacizumab in patients not candidates } \\
\text { for platinum, my scheme of choice is in combination } \\
\text { with weekly paclitaxel }\end{array}$ & & $\begin{array}{c}1 \\
\text { Fully } \\
\text { Disagr. }\end{array}$ & 2 & $\begin{array}{c}3 \\
\text { Fairly } \\
\text { Disagr }\end{array}$ & 4 & $\begin{array}{l}\mathbf{5} \\
\text { Neither } \\
\text { agree } \\
\text { nor } \\
\text { disagree }\end{array}$ & 6 & $\begin{array}{c}7 \\
\text { Fairly } \\
\text { Agree }\end{array}$ & 8 & $\begin{array}{c}9 \\
\text { Fully } \\
\text { Agree }\end{array}$ & & \\
\hline & $1^{\text {st }}$ & - & - & - & - & 6.5 & 6.5 & 19.4 & 29.0 & 38.7 & 87.1 & 8 \\
\hline $\begin{array}{l}\text { 6. In a priori patients not candidates for platinum due } \\
\text { to previous hypersensitivity reactions to carboplatin }\end{array}$ & & $\begin{array}{c}\mathbf{1} \\
\text { Fully } \\
\text { Disagr. }\end{array}$ & 2 & $\begin{array}{c}3 \\
\text { Fairly } \\
\text { Disagr }\end{array}$ & 4 & $\begin{array}{l}\mathbf{5} \\
\text { Neither } \\
\text { agree } \\
\text { nor } \\
\text { disagree }\end{array}$ & 6 & $\begin{array}{l}7 \\
\text { Fairly } \\
\text { Agree }\end{array}$ & 8 & $\begin{array}{c}9 \\
\text { Fully } \\
\text { Agree }\end{array}$ & & \\
\hline $\begin{array}{l}\text { a. I always try to retreat with desensitization } \\
\text { guidelines to carboplatin or cisplatin }\end{array}$ & $1^{\text {st }}$ & - & 3.2 & 3.2 & 0 & 12.9 & 3.2 & 38.7 & 16.1 & 22.6 & 77.4 & 7 \\
\hline $\begin{array}{l}\text { b. Usually, I prescribed a combination of pegylated } \\
\text { liposomal doxorubicin + trabectidine }\end{array}$ & $2^{\text {nd }}$ & 7,4 & 18.5 & 25.9 & - & - & 11.1 & 33.3 & 3.7 & - & 51.8 & 3 \\
\hline \multirow[t]{2}{*}{$\begin{array}{l}\text { 7. In a patient with a relapse initially considered not a } \\
\text { candidate for platinum for a TFIp }<6 \text { months and } \\
\text { who has been treated with several regimen lines } \\
\text { without platinum, obtaining a clinical benefit with } \\
\text { them and maintaining a good ECOG, I consider a } \\
\text { retreat with platinum }\end{array}$} & & $\begin{array}{c}1 \\
\text { Fully } \\
\text { Disagr. }\end{array}$ & 2 & $\begin{array}{l}3 \\
\text { Fairly } \\
\text { Disagr }\end{array}$ & 4 & $\begin{array}{l}\mathbf{5} \\
\text { Neither } \\
\text { agree } \\
\text { nor } \\
\text { disagree }\end{array}$ & 6 & $\begin{array}{l}7 \\
\text { Fairly } \\
\text { Agree }\end{array}$ & 8 & $\begin{array}{c}9 \\
\text { Fully } \\
\text { Agree }\end{array}$ & & \\
\hline & $1^{\text {st }}$ & - & - & - & - & 3.2 & 9.7 & 51.6 & 12.9 & 22.6 & 87.1 & 7 \\
\hline
\end{tabular}

\% C proportion of consensus, ECOG Eastern Cooperative Oncology Group, M Median, TFIp Treatment-free interval of platinum

Black shadowed areas represent the presence of consensus (i.e., $\geq 75 \%$ of the responses are located within those three consecutive points of the Likert scale) Gray shadowed areas represent the triplet with greater proportion of responses but without reaching the consensus threshold 
some key-and sometimes controversial-issues in the management of advanced ovarian cancer in Spain using a Delphi survey. Overall, we accounted for a large participation of the selected experts.

Initial extension assessment of the disease is a matter of discussion, and the latest ESMO-ESGO consensus recommends the necessity of standardization. CT, PETCT and diffusion-weighted whole-body MRI are among the imaging techniques that can be used in the initial workup [3]. According to the experts surveyed, the CT scan is the most common test to evaluate the disease stage at diagnosis. PET-CT is used less frequently, and diffusion-weighted whole-body MRI is rarely used, probably due to the more limited access to this technique. Although laparoscopy might provide a definite histopathological diagnosis and information on disease burden [3], according to our survey, it is not implemented as a first approach in all hospitals.

The goal of cytoreductive surgery must be complete cytoreduction, that is, the absence of macroscopic residual disease, since this is the most important prognostic factor in patients with advanced disease [13]. Several randomized clinical trials have shown no significant difference in progression free survival (PFS) and overall survival (OS) between PDS and IDS [14, 15]. However, most clinical practice guidelines recommend PDS when the patient has an adequate performance status and complete cytoreduction is considered feasible [3], since in these cases, the OS of patients with PDS could be longer than with IDS as reported in a retrospective study [16]. The results of this survey are consistent with this latter recommendation, and the respondents prefer PDS when the tumor is considered suitable for debulking, independent of FIGO stage III or IV. If IDS is an option, there was a strong agreement for recommending it after 3 cycles (and no more than 4 cycles) of NACT.

The combination of carboplatin and paclitaxel has been the first-line standard chemotherapy for over 20 years; other options include the administration of intraperitoneal therapy, which has been a matter of great debate, and the addition of bevacizumab as part of the first-line treatment [17]. There was no consensus for recommending intraperitoneal chemotherapy as firstline therapy, neither for patients with optimal debulking surgery nor for those with residual disease $\leq 1 \mathrm{~cm}$. However, more than $50 \%$ of respondents agreed that patients with optimal cytoreduction may receive intraperitoneal chemotherapy if they have adequate performance status. Although the GOG 172 study showed a benefit in terms of OS with the use of intraperitoneal chemotherapy, the recent results of the GOG 252 trial have cast doubt on the superiority of intraperitoneal administration, at least when bevacizumab is added to chemotherapy $[18,19]$.
The results of this survey reflect the debate around this approach among the oncology community.

In our survey, there was agreement for using bevacizumab for all patients with stage IV disease, both for those undergoing PDS and for those who require NACT and IDS. However, in patients with stage III disease, bevacizumab is only widely recommended if there is macroscopic residual disease $>1 \mathrm{~cm}$. The benefit of bevacizumab in stage III patients without residual disease has yet to be demonstrated, despite the results of an exploratory subgroup analysis of the ICON7 trial showing that the addition of bevacizumab to front-line chemotherapy improves PFS regardless of the stage or presence of residual disease [20]. The results of two randomized phase II trials did not show clear advantage for adding bevacizumab to neoadjuvant chemotherapy [21, 22]. However, the administration of bevacizumab after IDS might provide a benefit regardless of whether complete cytoreduction is achieved, as these patients are at higher risk of relapse due to greater tumor burden at diagnosis precluding PDS). Nevertheless, this hypothesis has not been proven, and therefore, most of the responders recommended restricting the use of bevacizumab after PDS for those patients with macroscopic residual disease.

Of note, the evaluation of the first-line treatment of this consensus was carried out without considering the recent results shown in the maintenance setting with PARPi, as at the time of modeling the first survey no PARPi had been approved in the front line [23-26].

The use of the 6-month cutoff of TFIp for defining platinum sensitivity or resistance has been abandoned in the ESMO-ESGO consensus, and a therapeutic-oriented definition is proposed classifying patients into two groups: those for whom platinum might not be the best option (defined by early symptomatic relapse, progression on prior platinum-based chemotherapy, or platinum intolerability) and those for whom platinum might be the best option or rechallenge appears justified (defined by a response to prior platinum-based chemotherapy and the absence of contraindications for platinum) [3]. Consistent with clinical guidelines, in our study the factors considered more relevant for selecting the treatment in patients with a TFIp exceeding 6 months were $B R C A$ mutation status, histological subtype and performance status; the location and extent of the disease, drugs and number of lines received, residual toxicity, presence of symptoms, comorbidities and patient preferences were also considered relevant.

Aligned with the ESMO-ESGO consensus, the respondents agreed that secondary debulking surgery should be offered to motivated patients with recurrent disease and a TFIp that exceeds 6 months if they meet the AGO score of the DESKTOP III study based on the benefit on PFS and OS recently communicated [27, 28]. Additionally, it 
would be advisable to perform PET-CT to have a better evaluation of the disease extension and therefore increase the likelihood of successful complete surgery, as agreed upon in this consensus. Although there are some case series that show a possible benefit with subsequent cytoreductive surgeries (tertiary or quaternary cytoreduction) $[29,30]$, the limited evidence available has not allowed consensus to be reached on this point.

In patients for whom platinum might be the best option, there was consensus on treating patients with $B R C A \mathrm{mu}-$ tations with a platinum-based combination followed by maintenance with PARPi (olaparib, niraparib or rucaparib), given the relevant benefit in terms of PFS shown in the SOLO2 [31], NOVA [32] and ARIEL3 trials [33]. Moreover, an improvement in OS was shown recently in the SOLO-2 trial [34]. There was also an agreement to analyze the status of somatic $B R C A$ in all patients who have a relapse when platinum might be the best option, and germline BRCA was non mutated at diagnosis.

However, there was no consensus for recommending platinum-based therapy followed by PARPi in patients without BRCA mutations. The ESMO-ESGO consensus states that in these cases, patients could be offered a platinum-based rechallenge either with bevacizumab or with PARPi maintenance in cases of response [3]. Platinum-based rechallenge plus bevacizumab is usually recommended for symptomatic patients for whom a rapid response is required, based on the higher response shown in the OCEANS [35] and GOG0213 [36] trials when bevacizumab is added to platinum-based chemotherapy. Consistently in our survey, there was also consensus that the presence of large ascites or pleural effusion were relevant factors for considering the option of adding bevacizumab to a platinum-based regimen in the first relapse after a TFIp >6 months. In the remaining patients, it would be advisable to opt for treatment with a platinum-based regimen followed by PARPi maintenance, based on the benefit in all subgroups showed by niraparib and rucaparib in NOVA [32] and ARIEL-3 [33] trials, respectively.

The role of trabectedin in the management of recurrent ovarian cancer is gradually being limited, and consistent with this, there is only consensus for recommending trabectedin in combination with pegylated liposomal doxorubicin (PLD) as a valid strategy for patients with a history of platinum hypersensitivity, regardless of the pTFI and $B R C A$ mutation status. Furthermore, with the availability of PARPis and their new indications, it is likely that the use of trabectedin plus PLD will be limited to patients who have received PARPi after prior platinum-based lines but still have a TFIp $>6$ months, especially for those patients with $B R C A$ mutated tumors for whom a subanalysis of the trial OVC-3006 has shown a benefit in OS compared to PLD [37].
Patients with recurrent ovarian cancer for whom platinum might not be the best option have a poor prognosis and obtain very limited benefits from currently available treatments. Therefore, for these patients, a clinical trial with new therapies might be one of the best options, and this was the opinion of most of the participants in our survey. When there is no option for clinical trial, the preferred therapeutic alternative according to the respondents is single-agent chemotherapy, with weekly paclitaxel being the agent of choice, in combination with bevacizumab when indicated [38]. Factors considered relevant in our survey for avoiding bevacizumab in these patients are a history of intestinal subocclusion, poor performance status, history of deep vein thrombosis or pulmonary thromboembolism, history of uncontrolled hypertension, and, to a lesser extent, several prior lines of treatment. These factors are fairly consistent with the exclusion criteria of the AURELIA trial that led to the approval of bevacizumab in this setting [39].

The results of the survey presented in this manuscript reflect therapeutic preferences on different topics of ovarian cancer treatment, expressed by a group of Spanish experts and systematized by the Delphi method. It is not possible to draw a global conclusion about the therapeutic recommendations for advanced ovarian cancer in our country due to the obvious limitation associated with the bias inherent to the selection of a limited number of participants who are considered national experts in the field. However, this survey shows a snapshot of current recommendations by this selected group of physicians. Although the majority of the agreements and recommendations are aligned with the recently published ESMO-ESGO consensus, there are some discrepancies that can be explained by differences in the interpretation of certain clinical trials, reimbursement or accessibility issues, making this type of survey a way to approach real clinical practices in specific countries.

\section{Methods}

\section{Expert panel and development of the questionnaire}

The scientific committee comprised three experts (AR, AO and AGM) who selected a group of medical oncologists and gynecologists throughout Spain with high expertise in the management of ovarian cancer to participate in this survey. The scientific committee, after revising the current literature and the clinical practice guidelines available at the time of the project initiation, developed a first version of the questionnaire. That version was revised by a group of $7 \mathrm{ex}$ perts-the review committee-who provided feedback on the questionnaire to the scientific committee, who then agreed on the final questionnaire (November 2018).

The questionnaire was divided into three areas concerning the treatment of advanced ovarian cancer: first- 
line treatment (10 questions), treatment of recurrent ovarian cancer in patients for whom platinum might be the best option (13 questions), and treatment of recurrent ovarian cancer in patients for whom platinum might not be the best option (7 questions). All questions but one were answered using a 9-item Likert-like scale with three types of answers: frequency $(1=$ never, $9=$ always), relevance ( $1=$ scarcely relevant, $9=$ very relevant) and agreement ( 1 = fully disagree, $9=$ fully agree $)$.

The project was scientifically endorsed by GEICO (the Spanish Ovarian Cancer Research Group).

\section{The Delphi method}

The Delphi method is a frequently used system for gathering opinions in a structured way from a group of experts [40]. The key characteristics of the method are the anonymous nature of the survey and that the participants receive feedback on their answers and may adjust their initial answers to that feedback using an iterative process [40].

We performed two rounds of administering the questionnaire via the internet on a website specifically designed for the study. The participants had to register on the website using a valid e-mail address and obtain a password in advance to fill out the questionnaire; however, the e-mail addresses were only known by the data manager in charge of the website. The website provided general instructions for completing the questionnaire and feedback on the number of questions remaining to be answered.

The first round took place between December 2018 and January 2019, and 32 experts were invited to participate. The answers from the first round were analyzed (see below) and were presented to the participants in an aggregate manner in a meeting that was held on May 24th, 2019. During the meeting, the scientific committee presented the results of the first round and promoted an open discussion on those questions, where a consensus (see definition below) was not reached. To facilitate the discussion among the attendees, they presented updated information (e.g., recommendations from clinical practice guidelines, results of clinical trials) on those questions.

The second round was carried out between June and July 2019, and using the same approach as in the first round, the participants only answered questions from the first round for which a consensus could not be reached. Questions that required a frequency answer were not included in this round since they were considered to reflect a situation/pattern instead of an opinion. To this end, each participant could look up the answer provided in the first round and modify his/her answer as appropriate.

\section{Statistical analysis}

Descriptive statistical analysis was performed using the absolute and relative frequencies of each answer in the corresponding Likert scale. Using a cutoff point described elsewhere [41], a consensus was considered reached when at least $75 \%$ of the answers were located within three consecutive points of the Likert scale. In addition to the proportion of consensus and its location on the 9-point Likert scale, the median was also calculated to determine the strength of the consensus [10].

\section{Abbreviations \\ AGO: Arbeitsgemeinschaft Gynäkologische Onkologie- German Working Group on Gynecological Oncology; CT: Computed tomography; GEICO: Spanish Ovarian Cancer Research Group; HRD: Homologous recombination deficiency; IDS: Interval debulking surgery; MRI: Magnetic resonance imaging; NACT: Neoadjuvant chemotherapy; OS: Overall survival; PARPi: PARP inhibitor; PDS: Primary debulking surgery; PET: Positron emission tomography; PFS: Progression free survival; PLD: Pegylated liposomal doxorubicin; TFIp: Treatment-free interval of platinum}

\section{Acknowledgements}

The authors wish to thank the following participants in this consensus (in alphabetical order): Jesús Alarcón (Palma, Spain), Ma José Bermejo (Málaga, Spain), Antonio Casado (Madrid, Spain), Luis Chiva (Pamplona, Spain), Cristina Churruca (Donostia-San Sebastián, Spain), Juan Cueva (Santiago de Compostela, Spain), Carmen Esteban (Toledo, Spain), Isaura Fernandez Perez (Vigo, Spain), José Fuentes (Sevilla, Spain), Elena García (Murcia, Spain), Santiago González-Santiago (Cáceres, Spain), Ma Mar Gordón (Jerez de la Frontera, Spain), Eva Guerra (Madrid, Spain), Ana Herrero (Zaragoza, Spain), Sergi Martínez (Badalona, Barcelona, Spain), Juana Oramas (Santa Cruz de Tenerife, Spain), Isabel Palacio (Oviedo, Spain), Beatriz Pardo (Barcelona, Spain), Alejandro Pérez Fidalgo (Valencia, Spain), Maria Quindós (A Coruña, Spain), Ana Santaballa (Valencia, Spain). The authors also wish to thank Alejandro Pedromingo (Bio-Estadística, Madrid, Spain) for the statistical analysis, Fernando Rico-Villademoros (COCIENTE S.L., Madrid, Spain) for his editorial assistance, and Sara Alonso (GSK, Madrid, Spain) for her assistance with administrative support and for the coordination of the project.

\section{Authors' contributions}

$A R, A O$ and $A G-M$ were members of the scientific committee and have participated in the conception, design, data analysis, interpretation of the results, and drafting of the manuscript; MJR, PB, AJ, LM, IR, CM and AP critically revised the survey questionnaire and the manuscript; all authors approved the final version of the manuscript.

\section{Funding}

This study was sponsored by TESARO without restriction, nowadays a GlaxoSmithkline company.

\section{Availability of data and materials}

Data is available upon request to the corresponding author.

\section{Declarations}

Ethics approval and consent to participate

This survey was conducted among physicians and no data on patients are presented.

\section{Consent for publication \\ Not applicable.}

\section{Competing interests}

A. Redondo reports honoraria and advisory/consultancy (MSD, AstraZeneca, Roche, GSK, Clovis, PharmaMar, Lilly, Amgen), research grant/funding to his institution (Eisai, PharmaMar, Roche), travel/accommodation/expenses (AstraZeneca, Tesaro, PharmaMar, Roche), and speakers bureau (MSD, AstraZeneca, Roche, GSK, Clovis, PharmaMar), outside the submitted work. A. Oaknin has served on advisory boards for Roche, AstraZeneca, PharmaMar, Clovis Oncology, Tesaro, Inmunogen and Genmab and received support for travel or accommodation from Roche, AstraZeneca, and PharmaMar; she also reports payments to the institution from Abbvie Deutschland, Abililty 
Pharmaceuticals, Advaxis Inc., Aeterna Zentaris, AMGEM, SA, Aprea Therapeutics AB, Clovis Oncology Inc., EISAl limited LTD, F. Hoffmann - La Roche LTD, Regeneron Pharmaceuticals, Immunogen Inc., Merck, Sharp \& Dohme de España SA, Millennium Pharmaceuticals Inc., Pharma Mar SA, Tesaro Inc., BMS, Bristrol Meyers Squibb.

M.J. Rubio has served on advisory boards for MSD, AstraZeneca, Roche, GSK, Clovis, PharmaMar and received support for travel or accommodation from Roche, AstraZeneca, and PharmaMar.

M-P. Barretina-Ginesta has served on Advisory boards for Roche, AstraZeneca, PharmaMar, Clovis Oncology, GSK, Merck Sharp \& Dohme; has received speaker bureau honoraria from AstraZeneca, Roche, PharmaMar, GSK, Clovis Oncology and received support for travel or accommodation from Roche, AstraZeneca, GSK and PharmaMar.

A. de Juan reports personal fees and other from Roche, AstraZeneca, Pharma Mar, Clovis Oncology, Tesaro, Eisai Ltd., Pierre-Fabre and Pfizer, outside the submitted work.

L. Manso has received advisory/consultancy honorarium from AstraZeneca, Clovis Oncology, Genmab, GSK, Merck Sharp \& Dohme, Novartis, Pfizer/ Merck, PharmaMar, Roche; has received speaker bureau/expert testimony honorarium from AstraZeneca, PharmaMar, Roche, GSK, Roche; has received research grant/funding from TESARO: A GSK Company; and has received travel/accommodation/expenses from AstraZeneca, Novartis, Roche, TESARO: A GSK Company.

I. Romero has received speaker's bureau honorarium from AstraZeneca, Pharmamar, GSK, Clovis, Roche; has received advisory board honorarium from AstraZeneca, GSK, Clovis, Roche; has received travel/expenses from AstraZeneca, Pharmamar, GSK, Roche; and has received research grant/ funding from Roche, GSK.

C. Martin-Lorente reports honoraria and advisory/consultancy (AstraZeneca, Clovis Oncology, GSK, MSD, PharmaMar, Roche); travel/accommodation/expenses (AstraZeneca, Clovis Oncology, GSK, MSD, PharmaMar, Roche); and speakers bureau (AstraZeneca, Clovis Oncology, GSK, MSD, PharmaMar, Roche).

A. Poveda has had a consulting or advisory role for AstraZeneca, PharmaMar, Roche, Clovis Oncology, and Tesaro; and has received travel/ accommodations/expenses from PharmaMar.

A. Gonzalez-Martín has received advisory/consultancy honorarium from Amgen, AstraZeneca, Clovis Oncology, Genmab, GSK, ImmunoGen, Merck Sharp \& Dohme, Novartis, Oncoinvent, Pfizer/Merck, PharmaMar, Roche, Sotio; has received speaker bureau/expert testimony honorarium from AstraZeneca, PharmaMar, Roche, GSK; has received research grant/funding from Roche, TESARO: A GSK Company; and has received travel/accommodation/expenses from AstraZeneca, Pharmamar, Roche, TESARO: A GSK Company.

\section{Author details}

${ }^{1}$ Medical Oncology Department, Hospital Universitario La Paz-IdiPAZ, Universidad Autónoma de Madrid, Paseo de la Castellana, 261, 28046 Madrid, Spain. ${ }^{2}$ Medical Oncology Department, Vall d'Hebron Institute of Oncology (VHIO), Hospital Universitari Vall d'Hebron, Vall d'Hebron Barcelona Hospital Campus, Barcelona, Spain. ${ }^{3}$ Medical Oncology Department, Hospital Universitario Reina Sofía, Universidad de Córdoba (UCO), Córdoba, Spain. ${ }^{4}$ Medical Oncology Department, Girona Biomedical Research Institute (IdIBGi) and Department of Medical Sciences, Catalan Institute of Oncology (ICO), Medical School University of Girona, Girona, Spain. ${ }^{5}$ Medical Oncology Department, Hospital Universitario Marqués de Valdecilla, Santander, Spain. ${ }^{6}$ Medical Oncology Department, Hospital Universitario 12 de Octubre-i+12, Madrid, Spain. ${ }^{7}$ Medical Oncology Department, Instituto Valenciano Oncologia, Valencia, Spain. ${ }^{8}$ Medical Oncology Department, Hospital Universitario de la Santa Creu i Sant Pau, Barcelona, Spain. ${ }^{9}$ Oncogynecologic Department, Initia Oncology, Hospital Quironsalud, Valencia, Spain. ${ }^{10}$ Medical Oncology Department, Clínica Universidad de Navarra, Madrid, Spain.

Received: 17 November 2020 Accepted: 26 April 2021

Published online: 26 May 2021

\section{References}

1. Bray F, Ferlay J, Soerjomataram I, Siegel RL, Torre LA, Jemal A. Global cancer statistics 2018: GLOBOCAN estimates of incidence and mortality worldwide for 36 cancers in 185 countries. CA Cancer J Clin. 2018;68(6):394-424. https://doi.org/10.3322/caac.21492.
2. Wright JD, Chen L, Tergas Al, Patankar S, Burke WM, Hou JY, et al. Trends in relative survival for ovarian cancer from 1975 to 2011. Obstet Gynecol. 2015; 125(6):1345-52. https://doi.org/10.1097/AOG.0000000000000854.

3. Colombo N, Sessa C, du Bois A, Ledermann J, McCluggage WG, McNeish I, et al. ESMO-ESGO consensus conference recommendations on ovarian cancer: pathology and molecular biology, early and advanced stages, borderline tumours and recurrent diseasedagger. Ann Oncol. 2019;30(5): 672-705. https://doi.org/10.1093/annonc/mdz062.

4. Francis J, Coakley N, Elit L, Mackay H. The gynecologic Cancer disease site group. Systemic therapy for recurrent epithelial ovarian cancer: a clinical practice guideline. Curr Oncol. 2017;24(6):e540-6. https://doi.org/10.3747/ co.24.3824.

5. Armstrong DK, Alvarez RD, Bakkum-Gamez JN, Barroilhet L, Behbakht K, Berchuck A, et al. NCCN guidelines insights: ovarian cancer, version 1.2019. J Natl Compr Cancer Netw. 2019;17(8):896-909. https://doi.org/10.6004/ jncen.2019.0039.

6. Santaballa A, Barretina P, Casado A, García Y, González-Martín A, Guerra E, et al. SEOM clinical guideline in ovarian cancer (2016). Clin Transl Oncol. 2016;18(12):1206-12. https://doi.org/10.1007/s12094-016-1588-8.

7. White KM, Seale H, Harrison R. Enhancing ovarian cancer care: a systematic review of guideline adherence and clinical variation. BMC Public Health. 2019;19(1):296. https://doi.org/10.1186/s12889-019-6633-4.

8. Funston G, Van Melle M, Baun MLL, Jensen H, Helsper C, Emery J, et al. Variation in the initial assessment and investigation for ovarian cancer in symptomatic women: a systematic review of international guidelines. BMC Cancer. 2019;19:1028.

9. Galvan-Turner VB, Chang J, Ziogas A, Bristow RE. Observed-to-expected ratio for adherence to treatment guidelines as a quality of care indicator for ovarian cancer. Gynecol Oncol. 2015;139(3):495-9. https://doi.org/10.1016/j. ygyno.2015.09.015

10. Warren JL, Harlan LC, Trimble EL, Stevens J, Grimes M, Cronin KA. Trends in the receipt of guideline care and survival for women with ovarian cancer: a population-based study. Gynecol Oncol. 2017;145(3):486-92. https://doi. org/10.1016/j.ygyno.2017.03.016.

11. Lee JY, Kim TH, Suh DH, Kim JW, Kim HS, Chung HH, et al. Impact of guideline adherence on patient outcomes in early-stage epithelial ovarian cancer. Eur J Surg Oncol. 2015;41(4):585-91. https://doi.org/10.1016/j.ejso.2015.01.006.

12. Boac BM, Xiong Y, Apte SM, Wenham RM, Shahzad MM, Munroe DG, et al. Adherence to practice guidelines is associated with reduced referral times for patients with ovarian cancer. Am J Obstet Gynecol. 2018;218:436.e1-7.

13. du Bois A, Reuss A, Pujade-Lauraine E, Harter P, Ray-Coquard I, Pfisterer J. Role of surgical outcome as prognostic factor in advanced epithelial ovarian cancer: a combined exploratory analysis of 3 prospectively randomized phase 3 multicenter trials. Cancer. 2009;115(6):1234-44. https://doi.org/10.1 002/cncr.24149

14. Vergote I, Tropé CG, Amant F, Kristensen GB, Ehlen T, Johnson N, et al. Neoadjuvant chemotherapy or primary surgery in stage IIIC or IV ovarian cancer. N Engl J Med. 2010;363(10):943-53. https://doi.org/10.1056/NEJMoa0908806.

15. Kehoe S, Hook J, Nankivell M, Jayson GC, Kitchener H, Lopes T, et al. Primary chemotherapy versus primary surgery for newly diagnosed advanced ovarian cancer (CHORUS): an open-label, randomised, controlled, noninferiority trial. Lancet. 2015;386(9990):249-57. https://doi.org/10.1016/S01406736(14)62223-6.

16. Chiva L, Lapuente F, Castellanos T, Alonso S, Gonzalez-Martin A. What should we expect after a complete cytoreduction at the time of interval or primary debulking surgery in advanced ovarian cancer? Ann Surg Oncol. 2015;23:1666-73.

17. Thigpen T, duBois A, McAlpine J, DiSaia P, Fujiwara K, Hoskins W, et al. Firstline therapy in ovarian cancer trials. Int J Gynecol Cancer. 2011;21(4):756-62. https://doi.org/10.1097/IGC.0b013e31821ce75d.

18. Armstrong DK, Bundy B, Wenzel L, Huang HQ, Baergen R, Lele S, et al. Intraperitoneal cisplatin and paclitaxel in ovarian cancer. N Engl J Med. 2006;354(1):34-43. https://doi.org/10.1056/NEJMoa052985.

19. Walker JL, Brady MF, Wenzel L, Fleming GF, Huang HQ, Disilvestro PA, et al. Randomized trial of intravenous versus intraperitoneal chemotherapy plus bevacizumab in advanced ovarian carcinoma: an NRG oncology/ gynecologic oncology group study. J Clin Oncol. 2019;37(16):1380-90. https://doi.org/10.1200/JCO.18.01568.

20. González Martín A, Oza AM, Embleton AC, Pfisterer J, Ledermann JA, Pujade-Lauraine $E$, et al. Exploratory outcome analyses according to stage 
and/or residual disease in the ICON7 trial of carboplatin and paclitaxel with or without bevacizumab for newly diagnosed ovarian cancer. Gynecol Oncol. 2019;152(1):53-60. https://doi.org/10.1016/j.ygyno.2018.08.036.

21. Garcia Garcia Y, de Juan FA, Mendiola C, Barretina-Ginesta MP, Gaba Garcia L, Santaballa Bertrán A, et al. Efficacy and safety results from GEICO 1205, a randomized phase II trial of neoadjuvant chemotherapy with or without bevacizumab for advanced epithelial ovarian cancer. Int J Gynecol Cancer. 2019;29(6):1050-6. https://doi.org/10.1136/ijgc-2019-000256.

22. Rouzier R, Gouy S, Selle F, Lambaudie E, Floquet A, Fourchotte V, et al. Efficacy and safety of bevacizumab-containing neoadjuvant therapy followed by interval debulking surgery in advanced ovarian cancer: results from the ANTHALYA trial. Eur J Cancer. 2017;70:133-42. https://doi.org/10.1 016/j.ejca.2016.09.036.

23. Moore K, Colombo N, Scambia G, Kim BG, Oaknin A, Friedlander M, et al. Maintenance olaparib in patients with newly diagnosed advanced ovarian cancer. N Engl J Med. 2018;379(26):2495-505. https://doi.org/10.1056/ NEJMoa1810858.

24. González-Martín A, Pothuri B, Vergote I, DePont CR, Graybill W, Mirza MR, et al. Niraparib in patients with newly diagnosed advanced ovarian cancer. N Engl J Med. 2019;381(25):2391-402. https://doi.org/10.1056/NEJMoa191 0962.

25. Ray-Coquard I, Pautier P, Pignata S, Pérol D, González-Martín A, Berger R, et al. Olaparib plus bevacizumab as first-line maintenance in ovarian cancer. N Engl J Med. 2019;381(25):2416-28. https://doi.org/10.1056/NEJMoa1911361.

26. Coleman RL, Fleming GF, Brady MF, Swisher EM, Steffensen KD, Friedlander $\mathrm{M}$, et al. Veliparib with first-line chemotherapy and as maintenance therapy in ovarian cancer. N Engl J Med. 2019;381(25):2403-15. https://doi.org/10.1 056/NEJMoa1909707.

27. Du Bois A, Sehouli J, Vergote I, Ferron G, Reuss A, Meier W, et al. Randomized phase III study to evaluate the impact of secondary cytoreductive surgery in recurrent ovarian cancer: final analysis of AGO DESKTOP III/ENGOT-ov20. J Clin Oncol. 2020;38(15_suppl):6000. https://doi. org/10.1200/JCO.2020.38.15_suppl.6000.

28. Du Bois A, Vergote I, Ferron G, Reuss A, Meier W, Greggi S, et al. Randomized controlled phase III study evaluating the impact of secondary cytoreductive surgery in recurrent ovarian cancer: AGO DESKTOP III/ENGOT ov20. J Clin Oncol. 2017;35(15_suppl):5501. https://doi.org/10.1200/JCO.201 7.35.15_suppl.5501.

29. Fotopoulou C, Savvatis K, Kosian P, Braicu IE, Papanikolaou G, Pietzner K, et al. Quaternary cytoreductive surgery in ovarian cancer: does surgical effort still matter? Br J Cancer. 2013;108(1):32-8. https://doi.org/10.1038/bjc.2012.544.

30. Fotopoulou C, Zang R, Gultekin M, Cibula D, Ayhan A, Liu D, et al. Value of tertiary cytoreductive surgery in epithelial ovarian cancer: an international multicenter evaluation. Ann Surg Oncol. 2012;20:1348-54.

31. Pujade-Lauraine E, Ledermann JA, Selle F, Gebski V, Penson RT, Oza AM, et al. Olaparib tablets as maintenance therapy in patients with platinumsensitive, relapsed ovarian cancer and a BRCA1/2 mutation (SOLO2/ENGOTOv21): a double-blind, randomised, placebo-controlled, phase 3 trial. Lancet Oncol. 2017;18(9):1274-84. https://doi.org/10.1016/S1470-2045(17)30469-2.

32. Mirza MR, Monk BJ, Herrstedt J, Oza AM, Mahner S, Redondo A, et al. Niraparib maintenance therapy in platinum-sensitive, recurrent ovarian cancer. N Engl J Med. 2016;375(22):2154-64. https://doi.org/10.1056/ NEJMoa1611310

33. Coleman RL, Oza AM, Lorusso D, Aghajanian C, Oaknin A, Dean A, et al. Rucaparib maintenance treatment for recurrent ovarian carcinoma after response to platinum therapy (ARIEL3): a randomised, double-blind, placebo-controlled, phase 3 trial. Lancet. 2017;390(10106):1949-61. https://doi.org/10.1016/S0140-6736(17)32440-6.

34. Poveda A, Floquet A, Ledermann JA, Asher R, Penson RT, Oza AM, et al. Final overall survival (OS) results from SOLO2/ENGOT-ov21: a phase III trial assessing maintenance olaparib in patients (pts) with platinum-sensitive, relapsed ovarian cancer and a BRCA mutation. J Clin Oncol. 2020;38(15_ suppl):6002. https://doi.org/10.1200/JCO.2020.38.15_suppl.6002.

35. Aghajanian C, Blank SV, Goff BA, Judson PL, Teneriello MG, Husain A, et al. OCEANS: a randomized, double-blind, placebo-controlled phase III trial of chemotherapy with or without bevacizumab in patients with platinumsensitive recurrent epithelial ovarian, primary peritoneal, or fallopian tube cancer. J Clin Oncol. 2012;30(17):2039-45. https://doi.org/10.1200/JCO.2 012.42.0505.

36. Coleman RL, Brady MF, Herzog TJ, Sabbatini P, Armstrong DK, Walker JL, et al. Bevacizumab and paclitaxel-carboplatin chemotherapy and secondary cytoreduction in recurrent, platinum-sensitive ovarian cancer (NRG oncology/gynecologic oncology group study GOG-0213): a multicentre, open-label, randomised, phase 3 trial. Lancet Oncol. 2017;18(6):779-91. https://doi.org/10.1016/S1470-2045(17)30279-6.

37. Monk BJ, Herzog TJ, Triantos S, Maul S, Wang G, Valero MJP, et al. Impact of prior pegylated liposomal doxorubicin (PLD) treatment in recurrent ovarian cancer (ROC): sub-group analysis from a randomized, open-label study comparing trabectedin (T) and PLD versus PLD alone in ROC (ET743-OVC-3006). Ann Oncol. 2019;30:v420-v1. https://doi.org/10.1093/annonc/mdz250.038.

38. Poveda AM, Selle F, Hilpert F, Reuss A, Savarese A, Vergote I, et al. Bevacizumab combined with weekly paclitaxel, pegylated liposomal doxorubicin, or topotecan in platinum-resistant recurrent ovarian cancer: analysis by chemotherapy cohort of the randomized phase III AURELIA trial. J Clin Oncol. 2015;33(32):3836-8. https://doi.org/10.1200/JCO.2015.63.1408.

39. Pujade-Lauraine E, Hilpert F, Weber B, Reuss A, Poveda A, Kristensen G, et al. Bevacizumab combined with chemotherapy for platinum-resistant recurrent ovarian cancer: the AURELIA open-label randomized phase III trial. J Clin Oncol. 2014;32(13):1302-8. https://doi.org/10.1200/JCO.2013.51.4489.

40. Diamond IR, Grant RC, Feldman BM, Pencharz PB, Ling SC, Moore AM, et al. Defining consensus: a systematic review recommends methodologic criteria for reporting of Delphi studies. J Clin Epidemiol. 2014;67(4):401-9. https:// doi.org/10.1016/j.jclinepi.2013.12.002.

41. Loblaw DA, Prestrud AA, Somerfield MR, Oliver TK, Brouwers MC, Nam RK, et al. American society of clinical oncology clinical practice guidelines: formal systematic review-based consensus methodology. J Clin Oncol. 2012;30(25):3136-40. https://doi.org/10.1200/JCO.2012.42.0489.

\section{Publisher's Note}

Springer Nature remains neutral with regard to jurisdictional claims in published maps and institutional affiliations.
Ready to submit your research? Choose BMC and benefit from:
- fast, convenient online submission
- thorough peer review by experienced researchers in your field
- rapid publication on acceptance
- support for research data, including large and complex data types
- gold Open Access which fosters wider collaboration and increased citations
- maximum visibility for your research: over $100 \mathrm{M}$ website views per year
At BMC, research is always in progress.
Learn more biomedcentral.com/submissions 